\title{
Analisis Kekuatan V-Core Sandwich Panel pada Geladak Kapal Menggunakan Metode Elemen Hingga
}

\author{
Hilda Dwi Febriani dan Dony Setyawan \\ Departemen Teknik Perkapalan, Fakultas Teknologi Kelautan \\ Institut Teknologi Sepuluh Nopember (ITS) \\ e-mail: dony@na.its.ac.id
}

\begin{abstract}
Abstrak-Sandwich panel adalah suatu struktur terdiri dari dua pelat yang relatif tipis disatukan dengan inti (core) dapat berupa material komposit atau material berbahan baja. Penggunaan material sandwich pada struktur bertujuan untuk membuat struktur lebih ringan. Kelebihan ini tentunya sangat bermanfaat terutama konstruksi pada kapal yang membutuhkan bahan penyusun yang ringan sehingga kecepatan kapal dan jumlah muatan yang dapat diangkut meningkat. Aspek yang perlu diperhatikan dalam penggunaan sandwich panel pada kapal adalah dari segi keamanannya sehingga didapatkan desain dimana tegangan dan deformasi memenuhi aturan kelas tetapi memiliki berat yang ringan. Salah satu tipe sandwich panel yang akan diteliti pada penelitian ini adalah v-core sandwich panel yang seluruh materialnya berbahan baja dan akan dibandingkan dengan pelat berpenegar. $V$-core sandwich panel adalah dua pelat yang disebut face dan disatukan dengan core berbentuk $v$. Terdapat 3 model $v$-core sandwich panel yang dibedakan dari ketinggian core-nya. Model 1 memiliki tinggi core $110 \mathrm{~mm}$, model 2 memiliki tinggi core $55 \mathrm{~mm}$ dan model 3 memiliki ketinggian core 220 mm. Ketiga model tersebut memiliki variasi ketebalan yang sama yang dibagi lagi menjadi variasi A sampai dengan variasi F. Variasi A dan Variasi D memiliki variasi ketebalan face dan core yang sama yaitu dari tebal $1 \mathrm{~mm}$ sampai $6 \mathrm{~mm}$. Variasi $B$, variasi $C$, variasi $E$ dan variasi $F$ memiliki variasi ketebalan face dan core yang berbeda-beda. Hasil percobaan didapatkan desain $v$-core sandwich panel yang paling optimal adalah desain pada model 1 dengan tinggi core $110 \mathrm{~mm}$, ketebalan face $5 \mathrm{~mm}$, ketebalan core $5 \mathrm{~mm}$, jarak antar core 62 $\mathrm{mm}$ dan lebar core $120 \mathrm{~mm}$ dengan besar tegangan yaitu 44,8 Mpa dimana nilai ini sudah kurang dari tegangan ijin dan kurang dari tegangan pelat berpenegar dengan besar deformasi $3,921 \mathrm{~mm}$ dan berat 28,5827 ton.
\end{abstract}

Kata Kunci-Sandwich panel, Tegangan, Deformasi, V-core, Finite Element Method.

\section{PENDAHULUAN}

K APAL merupakan alat transportasi yang digunakan untuk mengangkut penumpang dan barang. Seiring dengan perkembangan zaman, diharapkan teknologi saat ini mampu untuk menciptakan kapal yang cepat, ringan dan dapat mengangkut muatan dalam jumlah besar dengan tingkat keselamatan yang tinggi saat berlayar maupun bersandar. Kriteria tersebut dapat dicapai dengan melakukan inovasi pada bagian konstruksi kapal. Inovasi dilakukan dengan membuat konstruksi yang ringan namun kuat.

Saat ini telah dilakukan inovasi dari konstruksi dengan mengembangkan pelat yang dapat dipasang di kapal tanpa perlu menggunakan penegar yaitu sandwich panel. Sandwich panel secara umum merupakan gabungan dua pelat baja yang dipisahkan oleh core (inti). Core (inti) ini dapat berupa bahan komposit atau metal. Composite sandwich panel merupakan struktur yang terdiri dari bahan non-metallic seperti busa, poliuretan dan kayu balsa sedangkan untuk metallic sandwich panel merupakan struktur yang intinya dapat terbuat dari baja atau alumunium. Sandwich panel dapat menjadi solusi pengganti pelat konvensional yang pemasangan sebelumnya menggunakan penegar menjadi tanpa penegar. Bahan sandwich panel yang lebih ringan, memiliki ketahanan yang lebih baik terhadap korosi, getaran dan panas dari pada pelat konvensional hal tersebut dapat menjadi nilai tambah penggunaan sandwich panel pada konstruksi kapal terutama pada bagian geladak.

Penggunaan sandwich panel pada geladak kapal tentunya perlu memperhatikan aspek keamanan untuk memastikan kekuatan struktur geladak mampu bertahan dikenai beban. Oleh karena itu, tujuan dari penelitian ini adalah untuk mencegah kemungkinan bahaya yang akan terjadi jika sandwich panel diaplikasikan pada geladak kapal dan untuk mendapatkan desain, nilai tegangan, deformasi serta berat pada konstruksi geladak.

\section{STUDI LITERATUR}

\section{A. Penggunaan Sandwich Panel Pada Kapal}

Penggunaan sandwich panel pada kapal mulai dilakukan pada pertengahan tahun 1990 di Amerika oleh Angkatan Laut Amerika Serikat. Pengembangan sandwich panel terdiri dari pembuatan panel dengan tack welding konvensional dan laser welding selain itu dihitung juga estimasi dari kekuatan, ketahanan api dan ledakan sandwich panel. Dilakukan juga investigasi dasar tentang perbaikan dan pemeliharaan serta pengembangan core pada sandwich panel seperti corrugated core [1].

Sandwich panel merupakan pelat yang terdiri dari face plate dan core (inti) yang disatukan dengan spot welding, keling atau self tapping screw. Sandwich panel dapat terdiri dari material komposit yang terdiri dari komponen nonmetallic. Terdapat dua jenis panel metallic sandwich panel. Panel yang terdiri dari face plate baja yang disatukan dengan elastomer poliuretan contohnya (Sandwich Plate System) yang dikembangkan oleh Intellegend Engineering dan panel yang keseluruhannya baik face plate dan core merupakan struktur metal yang dilas bersama. Selama proses produksi core pada sandwich panel dapat diisi dengan mineral, busa, beton untuk meningkatkan kemampuan panel sesuai dengan target yang diinginkan [2].

\section{B. Tegangan}

Tegangan memiliki satuan gaya persatuan luas dan dilambangkan dengan huruf Yunani sigma $(\sigma)$. Secara umum tegangan yanng bekerja pada permukaan bidang mungkin 
seragam diseluruh area atau mungkin berbeda intensitasnya dari satu titik ke titik lainnya. Diasumsikan bahwa tekanan yang bekerja pada penampang didistribusikan merata di atas area tersebut. Kemudian resultan dari tekanan tersebut harus sama besarnya dengan tegangan dikali penampang melintang A dari bar [3].

Asumsi ini disederhanakan untuk mewakili tegangan, mewakili kuantitas vektor untuk banyak perhitungan teknik dan penentuan sifat material. Kata vektor biasanya mengacu pada kuantitas yang memiliki besar dan arah. Misalnya, tekanan pada bar yag digerakkan secara aksial sama dengan gaya yang diberikan dibagi dengan luas penampang batang [4].

$$
\sigma=\frac{\mathrm{F}}{\mathrm{A}}
$$

$$
\begin{aligned}
\text { Dimana: } & \mathrm{F}=\text { Gaya }(\mathrm{N}) \\
\mathrm{A} & =\operatorname{Luas} \text { Penampang }\left(\mathrm{m}^{2}\right) \\
\sigma & =\text { Tegangan }\left(\mathrm{N} / \mathrm{m}^{2} \text { atau Pascal }\right)
\end{aligned}
$$

Apabila gaya tersebut menyebabkan pertambahan panjang benda, maka disebut tegangan tensile. Jika gaya menyebabkan berkurangnya panjang benda maka tegangan tersebut disebut tegangan kompresional. Terdapat berbagai macam jenis tegangan meliputi tegangan normal, tegangan puntir, tegangan tarik, tegangan tekan dan tegangan lengkung [5].

\section{Tegangan Von Mises}

Menurut Houqe [6], tegangan von mises merupakan gabungan dari semua tegangan (tegangan geser dan tegangan normal pada tiga arah) yang berekasi pada titik tertentu. Tegangan von mises berguna untuk bahan yang tergolong ulet (ductile). Jika tegangan von mises di titik tertentu melebihi kekuatan luluh (yield strength), maka material akan mengalami kegagalan (putus) pada titik tersebut. Kriteria kegagalan menyatakan bahwa tegangan von mises $\sigma_{V M}$ harus kurang dari tegangan luluh (yield stress) $\sigma_{\mathrm{y}}$ dari material.

\section{Safety Factor dan Tegangan Ijin}

Kegagalan suatu struktur dapat diminimalisir dengan mengusahakan beban penyangga struktur harus lebih besar dari pada beban luar yang mengenainya. Karena kekuatan adalah kemampuan suatu struktur untuk dapat menahan beban, maka kriteria sautu struktur kuat adalah sebagai berikut:

- Kekuatan sebenarnya harus melebihi kekuatan yang diijinkan.

- Rasio kekuatan sebenarnya dengan kekuatan ijin disebut faktor keamanan (n).

Faktor Keamanan $=\frac{\text { Kekuatan Sebenarnya }}{\text { Kekuatan Ijin }}$

Nilai dari faktor keamanan harus lenbih besar dari 1,0 agar tidak terjadi kegagalan. Jika faktor keamanan sangat rendah, kemugkinan kegagalan akan tinggi dan struktur tidak dapat diterima. Jika faktor keamanan terlalu besar, struktur tersebut akan boros bahan dan mungkin tidak sesuai untuk fungsinya (misalnya, terlalu berat). Karena kompleksitas dan ketidakpastian ini, faktor keamanan harus ditentukan secara probabilistik.

Faktor keamanan didefinisikan dan diimplementasikan dengan banyak cara. Untuk banyak struktur, sangat penting agar material tetap berada di range elastic linier guna menghindari deformasi ketika sudah tidak dikenai beban oleh karena itu, faktor keamanan digunakan unutk mengukur kemampuan struktur luluh (yielding) yang terjadi saat tegangan luluh (yield stress) tercapai pada setiap titik di dalam struktur. Karena itu, dengan menerapkan faktor keamanan, didapatkan nilai tegangan yang bekerja pada strutur tersebut tidak boleh melebihi tegangan yang diijinkan.

$$
\text { Tegangan Ijin }=\frac{\text { Kuat Luluh }}{\text { Faktor Keamanan }}
$$

Atau untuk tegangan dan shear,

$$
\sigma_{i j i n}=\frac{\sigma_{y}}{n_{1}} \text { dan } \tau_{i j i n}=\frac{\tau_{y}}{n_{2}}
$$

Dimana $\sigma_{\mathrm{y}}$ dan $\tau_{\mathrm{y}}$ adalah tegangan luluh, $\mathrm{n}_{1}$ dan $\mathrm{n}_{2}$ adalah nilai faktor keamanan [3].

\section{E. Metode Elemen Hingga}

Metode Elemen hingga (FEM) adalah metode numerik untuk memcahkan masalah teknik dan fisika matematika. Bidang masalah yang khas termasuk analisis struktural, perpindahan panas, aliran fluida, mass transport dan potensi elektromagnetik. Perumusan metode elemen hingga dari suatu masalah menghasilkan sistem persamaan aljabar [7].

Penyelesaian yang didapat untuk masalah struktur adalah deformasi (displacement) pada setiap titik (nodes) yang selanjutnya digunakan untuk mendapatkan besaran-besaran regangan (strain) dan tegangan (stress). Keunggulan dari metode ini adalah memberikan solusi sangat efisien dan cukup akurat. Pemilihan tipe elemen diutamakan bergantung pada tujuan dari analisis. Karakteristik dari elemen yang dipilih harus dapat merepresentasikan secara akurat kondisi alami dari sebuah struktur dan tegangan yang akan dianalisis. Ketika melakukan analisis tegangan, pengetahuan terkait karakteristik elemen harus memadai mengingat karakteristik elemen adalah sebuah prasyarat dari suatu pengerjaan analisis struktur [8].

\section{METEDOLOGI PENELITIAN}

\section{A. Pengumpulan Data}

Proses pengerjaan studi ini dilakukan dengan memodelkan dan menganalisis geladak kapal sehingga diperlukan datadata pendukung sebagai dasar dalam membuat model. Dalam penelitian ini digunakan data kapal Tanker 17500 Double Hull LTDW. Adapun ukuran utama dari kapal tersebut dijelaskan pada Tabel 1.

Tabel 1.

Ukuran Utama Kapal Tanker 17500 Double Hull LTDW

\begin{tabular}{ccc}
\hline \hline Principal Dimensions & \\
\hline Length (L) & 149,76 & $\mathrm{~m}$ \\
Breadth (B) & 27,7 & $\mathrm{~m}$ \\
Depth (D) & 12 & $\mathrm{~m}$ \\
Draft (d) & 7 & $\mathrm{~m}$ \\
Block Coefficient (Cb=^/LBD) & 0,82 & \\
\hline \hline
\end{tabular}

\section{B. Pemodelan}

Pemodelan geladak kapal berpenegar dan geladak dengan $v$-core sandwich panel dibuat dengan software elemen hingga. Terdapat 1 model untuk geladak berpenegar dengan ukuran pelat 17400x12500x15 mm dan ukuran profil L 221x11x44x22 mm. Geladak dengan v-core sandwich panel dibuat 3 model dengan perbedaan tinggi core yaitu $110 \mathrm{~mm}$, $55 \mathrm{~mm}$ dan $220 \mathrm{~mm}$. Variasi ketebalan $v$-core sandwich panel dari 1 s/d 6 mm. Dimana tebal face disebut tf dan tebal core disebut tc. Berikut akan ditampilkan ilustrasi ukuran v-core sandwich panel model 1 sampai model 3 pada Gambar 1 s/d Gambar 3. 


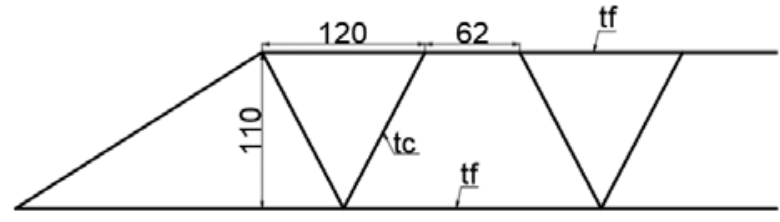

Gambar 1. V-Core Sandwich Panel Model 1

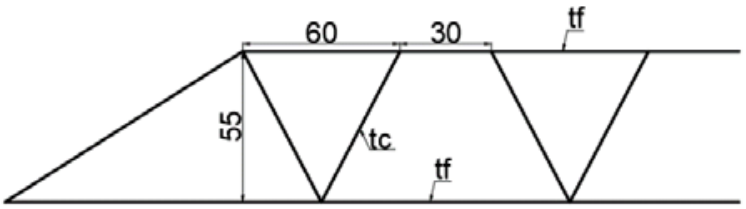

Gambar 2. V-Core Sandwich Panel Model 2

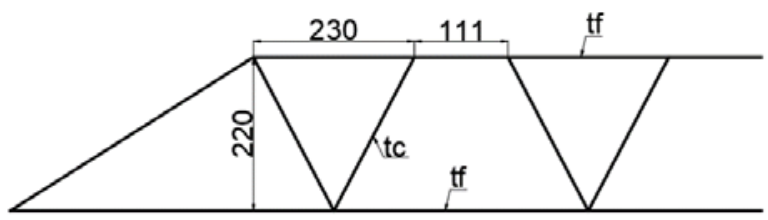

Gambar 3. V-Core Sandwich Panel Model 3

\section{Analisis Tegangan}

Analisis tegangan pada model baik model geladak berpenegar dan model geladak dengan $v$-core sandwich panel dilakukan dengan membandingkan tegangan ijin material baja dengan tegangan hasil analisis oleh software elemen hingga. Jika tegagan model melebihi tegangan ijin maka desain model perlu ditinjau ulang.

\section{Alur Pengerjaan}

Secara sistematis langkah-langkah pengerjaan studi disajikan dalam bentuk diagram alir sebagai berikut:

Langkah kerja tersebut adalah sebagai berikut:

- Pengumpulan Data

Dalam proses ini dilakukan studi literatur yang bertujuan untuk merumuskan masalah yang berkaitan dengan penelitian yang akan dianalisis.

- Penentuan Variasi Model

Terdapat satu model geladak berpenegar dan 3 model geladak dengan $v$-core sandwich panel yang dibedakan berdasarkan tinggi core. V-core sandwich panel juga dimodelkan dengan variasi ketebalan pelat yang digunakan.

- Pemodelan

Pemodelan geometri model dilakukan secara lokal pada geladak kapal dengan memodelkan profile, pelat dan pelintang untuk geladak berpenegar dan memodelkan geladak tanpa penegar dimana pelat geladak diganti $v$-core sandwich panel. Pemodelan ini dilakukan untuk mendapatkan tegangan yang terjadi pada geladak berpenegar dan geladak dengan $v$ core sandwich panel untuk dianalisis.

- Konvergensi

Tahapan ini dilakukan untuk memverifikasi tegangan yang terjadi pada model dengan melakukan optimasi meshing pada software untuk mendapatkan nilai tegangan yang konstan pada ukuran meshing optimal untuk analisis selanjutnya.

- Pembebanan

Jika konvergensi telah tercapai selanjutnya pemberian beban untuk analisa. Beban yang digunakan adalah beban lateral sebesar $10 \mathrm{kN} / \mathrm{m}^{2}$. Nilai tersebut didapatkan dari perhitungan beban statis untuk beban pada geladak.

\section{- Analisis Tegangan}

Konvergensi model pada tahap sebelumnya berfungsi untuk menentukan ukuran meshing untuk tahap ini. Tegangan yang dihasilkan digunakan untuk analisis kekuatan.

\section{- Penerimaan Tegangan}

Tegangan pada geladak dengan $v$-core sandwich panel yang dihasilkan dari hasil analisis FEA dibandingkan dengan tegangan yang diizinkan oleh kelas dan tegangan yang dihasilkan oleh geladak berpenegar. Besar deformasi model juga perlu ditinjau.

\section{- Perhitungan Berat}

Model yang telah didapatkan nilai tegangan dan deformasinya, kemudian dihitung beratnya. Berat model vcore sandwich panel harus lebih ringan dari pada berat geladak berpenegar.

\section{ANALISIS DAN PEMBAHASAN}

\section{A. Analisis Tegangan dan Deformasi}

Hasil simulasi yang dilakukan telah dijelaskan pada subbab sebelumnya didapatkan nilai tegangan, deformasi dan berat antara geladak berpenegar dengan geladak $v$-core sandwich panel yang dapat ditampilkan pada bentuk tabel pada Tabel 2 sampai dengan Tabel 7. Hasil rekapitulasi tabel dibawah merupakan rekapitulasi hasil running geladak dengan $v$-core sandwich panel yang dibagi menjadi 3 model. Setiap model berisi dua jenis rekapitulasi yaitu rekapitulasi tebal face $1-6 \mathrm{~mm}$ dengan variasi core 5-6mm dan tebal core 1-6mm dengan variasi face 5-6mm. Hasil tersebut selanjutnya akan dibandingkan dengan hasil running geladak berpenegar dimana didapatkan besar tegangan 46,7 Mpa dan deformasi 3,886mm.

Tabel 2.

Hasil Tegangan dan Deformasi untuk Tebal Face Geladak Geladak V-Core Sandwich Panel Model 1.

\begin{tabular}{|c|c|c|c|c|c|c|c|c|c|c|}
\hline \multicolumn{11}{|c|}{ GELADAK DENGAN V-CORE SANDWICH PANEL H=110 mm } \\
\hline \multirow[b]{2}{*}{ Jenis Pelat } & \multirow[b]{2}{*}{$\begin{array}{c}\mathrm{tf} \\
(\mathrm{mm})\end{array}$} & \multicolumn{3}{|c|}{ Variasi A } & \multicolumn{3}{|c|}{ Variasi B } & \multicolumn{3}{|c|}{ Variasi C } \\
\hline & & $\begin{array}{c}\text { Tc } \\
\text { (Mpa) }\end{array}$ & $\begin{array}{c}\text { Tegangan } \\
\text { (Mpa) }\end{array}$ & $\begin{array}{c}\text { Deformasi } \\
(\mathrm{mm})\end{array}$ & $\begin{array}{c}\text { tc } \\
\text { (Mpa) }\end{array}$ & $\begin{array}{c}\text { Tegangan } \\
\text { (Mpa) }\end{array}$ & $\begin{array}{c}\text { Deformasi } \\
\text { (mm) }\end{array}$ & $\begin{array}{c}\text { tc } \\
\text { (Mpa) }\end{array}$ & $\begin{array}{l}\text { Tegangan } \\
\text { (Mpa) }\end{array}$ & $\begin{array}{l}\text { Deformasi } \\
\text { (mm) }\end{array}$ \\
\hline \multirow{6}{*}{$\begin{array}{l}\text { Sandwich } \\
\text { Panel }\end{array}$} & 1 & 1 & 309 & 7.365 & 5 & 269 & 5.82 & 6 & 268 & 5.689 \\
\hline & 2 & 2 & 110 & 5.134 & 5 & 101 & 4.772 & 6 & 99.3 & 4.696 \\
\hline & 3 & 3 & 68.2 & 4.455 & 5 & 65 & 4.314 & 6 & 63.7 & 4.261 \\
\hline & 4 & 4 & 51.3 & 4.093 & 5 & 49 & 4.063 & 6 & 48 & 4.038 \\
\hline & 5 & 5 & 44.8 & 3.921 & 5 & 44.8 & 3.921 & 6 & 44.7 & 3.9 \\
\hline & 6 & 6 & 44 & 3.795 & 5 & 44.1 & 3.812 & 6 & 44 & 3.795 \\
\hline
\end{tabular}


Tabel 3.

Hasil Tegangan dan Deformasi untuk Tebal Core Geladak Geladak V-Core Sandwich Panel Model 1

\begin{tabular}{|c|c|c|c|c|c|c|c|c|c|c|}
\hline \multicolumn{11}{|c|}{ GELADAK DENGAN V-CORE SANDWICH PANEL H=110 mm } \\
\hline \multirow[b]{2}{*}{ Jenis Pelat } & \multirow[b]{2}{*}{$\begin{array}{c}\text { tf } \\
(\mathbf{m m})\end{array}$} & \multicolumn{3}{|c|}{ Variasi D } & \multicolumn{3}{|c|}{ Variasi E } & \multicolumn{3}{|c|}{ Variasi F } \\
\hline & & $\begin{array}{c}\text { tc } \\
\text { (Mpa) }\end{array}$ & $\begin{array}{c}\text { Tegangan } \\
\text { (Mpa) }\end{array}$ & $\begin{array}{c}\text { Deformasi } \\
(\mathrm{mm})\end{array}$ & $\begin{array}{c}\text { tc } \\
\text { (Mpa) }\end{array}$ & $\begin{array}{c}\text { Tegangan } \\
\text { (Mpa) }\end{array}$ & $\begin{array}{c}\text { Deformasi } \\
\text { (mm) }\end{array}$ & $\begin{array}{c}\text { tc } \\
\text { (Mpa) }\end{array}$ & $\begin{array}{l}\text { Tegangan } \\
\text { (Mpa) }\end{array}$ & $\begin{array}{c}\text { Deformasi } \\
\text { (mm) }\end{array}$ \\
\hline \multirow{6}{*}{$\begin{array}{l}\text { Sandwich } \\
\text { Panel }\end{array}$} & 1 & 1 & 309 & 7.365 & 5 & 152 & 4.109 & 6 & 139 & 3.983 \\
\hline & 2 & 2 & 110 & 5.134 & 5 & 92.8 & 4.017 & 6 & 87.1 & 3.895 \\
\hline & 3 & 3 & 68.2 & 4.455 & 5 & 66.4 & 3.975 & 6 & 63.4 & 3.858 \\
\hline & 4 & 4 & 51.3 & 4.093 & 5 & 51 & 3.945 & 6 & 49.3 & 3.832 \\
\hline & 5 & 5 & 44.8 & 3.921 & 5 & 44.8 & 3.921 & 6 & 44.1 & 3.812 \\
\hline & 6 & 6 & 44 & 3.795 & 5 & 44.7 & 3.9 & 6 & 44 & 3.795 \\
\hline
\end{tabular}

Tabel 4.

Hasil Tegangan dan Deformasi untuk Tebal Face Geladak V-Core Sandwich Panel Model 2

\begin{tabular}{|c|c|c|c|c|c|c|c|c|c|c|}
\hline \multicolumn{11}{|c|}{ GELADAK DENGAN V-CORE SANDWICH PANEL H=55 mm } \\
\hline \multirow[b]{2}{*}{ Jenis Pelat } & \multirow[b]{2}{*}{$\begin{array}{c}\mathbf{t f} \\
(\mathbf{m m})\end{array}$} & \multicolumn{3}{|c|}{ Variasi A } & \multicolumn{3}{|c|}{$\begin{array}{c}\text { Variasi B } \\
\end{array}$} & \multicolumn{3}{|c|}{ Variasi C } \\
\hline & & $\begin{array}{c}\text { tc } \\
\text { (Mpa) }\end{array}$ & $\begin{array}{c}\text { Tegangan } \\
\text { (Mpa) }\end{array}$ & $\begin{array}{c}\text { Deformasi } \\
\text { (mm) }\end{array}$ & $\begin{array}{c}\text { tc } \\
\text { (Mpa) }\end{array}$ & $\begin{array}{c}\text { Tegangan } \\
\text { (Mpa) }\end{array}$ & $\begin{array}{c}\text { Deformasi } \\
(\mathrm{mm})\end{array}$ & $\begin{array}{c}\text { tc } \\
\text { (Mpa) } \\
\end{array}$ & $\begin{array}{c}\text { Tegangan } \\
\text { (Mpa) }\end{array}$ & $\begin{array}{c}\text { Deformasi } \\
(\mathrm{mm})\end{array}$ \\
\hline \multirow{6}{*}{$\begin{array}{l}\text { Sandwich } \\
\text { Panel }\end{array}$} & 1 & 1 & 338 & 12.661 & 5 & 246 & 9.346 & 6 & 232 & 8.894 \\
\hline & 2 & 2 & 179 & 8.374 & 5 & 109 & 7.419 & 6 & 111 & 7.185 \\
\hline & 3 & 3 & 115 & 6.75 & 5 & 80.6 & 6.397 & 6 & 84.6 & 6.248 \\
\hline & 4 & 4 & 83.7 & 5.862 & 5 & 72.9 & 5.747 & 6 & 65.4 & 5.642 \\
\hline & 5 & 5 & 66.1 & 5.292 & 5 & 66.1 & 5.292 & 6 & 60 & 5.213 \\
\hline & 6 & 6 & 55.2 & 4.889 & 5 & 60 & 4.951 & 6 & 55.2 & 4.889 \\
\hline
\end{tabular}

Tabel 5.

Hasil Tegangan dan Deformasi untuk Tebal Core Geladak Geladak V-Core Sandwich Panel Model 2

\begin{tabular}{|c|c|c|c|c|c|c|c|c|c|c|}
\hline \multicolumn{11}{|c|}{ GELADAK DENGAN V-CORE SANDWICH PANEL H=55 mm } \\
\hline \multirow[b]{2}{*}{ Jenis Pelat } & \multirow[b]{2}{*}{ tf (mm) } & \multicolumn{3}{|c|}{ Variasi D } & \multicolumn{3}{|c|}{ Variasi E } & \multicolumn{3}{|c|}{ Variasi F } \\
\hline & & $\begin{array}{c}\text { tc } \\
\text { (Mpa) }\end{array}$ & $\begin{array}{c}\text { Tegangan } \\
\text { (Mpa) }\end{array}$ & $\begin{array}{c}\text { Deformasi } \\
(\mathrm{mm})\end{array}$ & $\begin{array}{c}\text { tc } \\
\text { (Mpa) }\end{array}$ & $\begin{array}{l}\text { Tegangan } \\
\text { (Mpa) }\end{array}$ & $\begin{array}{c}\text { Deformasi } \\
(\mathrm{mm})\end{array}$ & $\begin{array}{c}\text { tc } \\
\text { (Mpa) }\end{array}$ & $\begin{array}{c}\text { Tegangan } \\
\text { (Mpa) }\end{array}$ & $\begin{array}{l}\text { Deformasi } \\
(\mathrm{mm})\end{array}$ \\
\hline \multirow{5}{*}{$\begin{array}{l}\text { Sandwich } \\
\text { Panel }\end{array}$} & 1 & 1 & 338 & 12.661 & 5 & 169 & 5.752 & 6 & 143 & 5.327 \\
\hline & 2 & 2 & 179 & 8.374 & 5 & 110 & 5.585 & 6 & 95.6 & 5.184 \\
\hline & 3 & 3 & 115 & 6.75 & 5 & 86.5 & 5.472 & 6 & 75.3 & 5.094 \\
\hline & 5 & 5 & 66.1 & 5.292 & 5 & 66.1 & 5.292 & 6 & 60 & 4.951 \\
\hline & 6 & 6 & 55.2 & 4.889 & 5 & 60 & 5.213 & 6 & 55.2 & 4.889 \\
\hline
\end{tabular}

Tabel 6.

Hasil Tegangan dan Deformasi untuk Tebal Face Geladak V-Core Sandwich Panel Model 3

\begin{tabular}{|c|c|c|c|c|c|c|c|c|c|c|}
\hline \multicolumn{11}{|c|}{ GELADAK DENGAN V-CORE SANDWICH PANEL H=220 mm } \\
\hline \multirow[b]{2}{*}{ Jenis Pelat } & \multirow[b]{2}{*}{ tf (mm) } & \multicolumn{3}{|c|}{ Variasi A } & \multicolumn{3}{|c|}{ Variasi B } & \multicolumn{3}{|c|}{ Variasi C } \\
\hline & & $\begin{array}{c}\text { tc } \\
\text { (Mpa) }\end{array}$ & $\begin{array}{c}\text { Tegangan } \\
\text { (Mpa) }\end{array}$ & $\begin{array}{c}\text { Deformasi } \\
\text { (mm) }\end{array}$ & $\begin{array}{c}\text { tc } \\
\text { (Mpa) }\end{array}$ & $\begin{array}{c}\text { Tegangan } \\
\text { (Mpa) }\end{array}$ & $\begin{array}{c}\text { Deformasi } \\
\text { (mm) }\end{array}$ & $\begin{array}{c}\text { tc } \\
\text { (Mpa) }\end{array}$ & $\begin{array}{c}\text { Tegangan } \\
\text { (Mpa) }\end{array}$ & $\begin{array}{c}\text { Deformasi } \\
(\mathrm{mm})\end{array}$ \\
\hline \multirow{5}{*}{$\begin{array}{l}\text { Sandwich } \\
\text { Panel }\end{array}$} & 1 & 1 & 992 & 79.545 & 5 & 884 & 60.878 & 6 & 883 & 60.711 \\
\hline & 2 & 2 & 256 & 9.737 & 5 & 229 & 7.786 & 6 & 228 & 7.653 \\
\hline & 3 & 3 & 130 & 4.387 & 5 & 121 & 4.259 & 6 & 119 & 4.221 \\
\hline & 5 & 5 & 62.2 & 3.781 & 5 & 62.2 & 3.781 & 6 & 61.2 & 3.758 \\
\hline & 6 & 6 & 49.4 & 3.628 & 5 & 50 & 3.648 & 6 & 49.4 & 3.652 \\
\hline
\end{tabular}

Tabel 7.

Hasil Tegangan dan Deformasi untuk Tebal Core Geladak V-Core Sandwich Panel Model 3

\begin{tabular}{|c|c|c|c|c|c|c|c|c|c|c|}
\hline \multicolumn{11}{|c|}{ GELADAK DENGAN V-CORE SANDWICH PANEL H=220 mm } \\
\hline \multirow[b]{2}{*}{ Jenis Pelat } & \multirow[b]{2}{*}{ tf (mm) } & \multicolumn{3}{|c|}{ Variasi D } & \multicolumn{3}{|c|}{ Variasi E } & \multicolumn{3}{|c|}{ Variasi F } \\
\hline & & $\begin{array}{c}\text { tc } \\
\text { (Mpa) }\end{array}$ & $\begin{array}{c}\text { Tegangan } \\
\text { (Mpa) }\end{array}$ & $\begin{array}{c}\text { Deformasi } \\
\text { (mm) }\end{array}$ & $\begin{array}{c}\text { tc } \\
\text { (Mpa) }\end{array}$ & $\begin{array}{c}\text { Tegangan } \\
\text { (Mpa) }\end{array}$ & $\begin{array}{c}\text { Deformasi } \\
\text { (mm) }\end{array}$ & $\begin{array}{c}\text { tc } \\
\text { (Mpa) }\end{array}$ & $\begin{array}{c}\text { Tegangan } \\
\text { (Mpa) }\end{array}$ & $\begin{array}{c}\text { Deformasi } \\
(\mathrm{mm})\end{array}$ \\
\hline \multirow{5}{*}{$\begin{array}{l}\text { Sandwich } \\
\text { Panel }\end{array}$} & 1 & 1 & 992 & 79.545 & 5 & 134 & 3.978 & 6 & 134 & 3.804 \\
\hline & 2 & 2 & 256 & 9.737 & 5 & 87.3 & 3.889 & 6 & 89.3 & 3.727 \\
\hline & 3 & 3 & 130 & 4.387 & 5 & 66.6 & 3.843 & 6 & 67.7 & 3.695 \\
\hline & 5 & 5 & 62.2 & 3.781 & 5 & 62.2 & 3.781 & 6 & 50 & 3.648 \\
\hline & 6 & 6 & 49.4 & 3.628 & 5 & 61.2 & 3.758 & 6 & 49.4 & 3.628 \\
\hline
\end{tabular}

Berdasarkan hasil rekapitulasi pada Tabel 2 sampai dengan sandwich panel yang kurang dari tegangan geladak Tabel 19 nilai tegangan pada geladak dengan $v$-core berpenegar adalah pada tebal 5-5-5 mm, 5-6-5 mm, 6-5-6 mm 
dan 6-6-6 mm dengan besar tegangan berturut-turut adalalah 44,8 Mpa, 44,7 Mpa, 44,1 Mpa dan 44 Mpa. Deformasi dari tebal tersebut berturut-turut adalah 3,921 mm, 3,9 mm, 3,812 mm dan 3,795.

\section{B. Berat Konstruksi}

Berat konstruksi geladak berpenegar akan dibandingkan dengan geladak dengan $v$-core sandwich panel dan dicari berat geladak $v$-core sandwich panel yang lebih rendah dari geladak berpenegar dengan tegangan yang lebih kecil dari pada tegangan geladak berpenegar. Didapatkan berat konstruksi geladak berpenegar adalah 34 ton sesuai dengan perhitungan yan telah dilakukan. Berdasarkan Tabel 2 sampai Tabel 19 geladak $v$-core sandwich panel yang tegangan nya lebih kecil dari geladak berpenegar yaitu pada tebal 5-5-5 mm, 5-6-5 mm, 6-5-6 mm dan 6-6-6 mm `model 1 sedangkan untuk model 2 dan model 3 dari keseluruhan variasi tebal nilai tegangannya masih lebih dari tegangan geladak berpenegar. Berikut akan ditampilkan perbandingan berat untuk model 1 yang tegangannya kurang dari tegangan geladak berpenegar pada Tabel 8 .

Tabel 8.

Berat Geladak Berpenegar dan Geladak dengan V-Core Sandwich Panel

\begin{tabular}{cccc}
\hline \hline Jenis Pelat & $\begin{array}{c}\text { Tebal } \\
\text { (mm) }\end{array}$ & Berat (ton) & $\begin{array}{c}\text { Perbedaan Berat } \\
\text { (\%) }\end{array}$ \\
\hline Geladak Berpenegar & - & 34.174818 & - \\
& $5-5-5$ & 28.582075 & $16 \%$ \\
Sandwich Panel & $5-6-5$ & 30.875442 & $10 \%$ \\
& $6-5-6$ & 32.005123 & $6 \%$ \\
& $6-6-6$ & 34.29849 & $0 \%$ \\
\hline \hline
\end{tabular}

Berdasarkan hasil rekapitulasi Tabel 8, v-core sandwich panel yang dapat digunakan sebagai bahan pertimbangan alternatiff pengganti geladak berpenegar adalah pada $v$-core sandwich panel dengan ketebalan 5-5-5 mm, 5-6-5 mm dan 6-5-6 mm. Tebal pelat 6-6-6 mm tidak dapat digunakan karena beratnya sama dengan berat geladak berpenegar.

\section{Pembahasan Model Optimal}

Model geladak kapal yang optimal antara geladak berpenegar dan geladak sandwich panel diambil dari hasil analisis antara model 1 sampai model 3. Pengambilan model yang optimal didasarkan pada hasil tegangan maksimum, deformasi maksimum, dan berat minimum. Apabila dilihat dari segi tegangan geladak sandwich panel harus memiliki tegangan kurang dari tegangan yang diijinkan dan tegangan geladak berpenegar. Tegangan yang dijinkan adalah 175 $\mathrm{N} / \mathrm{mm} 3$ sedangkan tegangan geladak berpenegar adalah 46,7 Mpa Ketinggian core juga mempengaruhi tegangan dan deformasi pada model. Terlihat nilai tegangan paling baik terdapat pada sandwich panel dengan ketinggian $110 \mathrm{~mm}$. Hal ini dikarenakan momen inersia pada model 1 lebih besar dari momen inersia model 2. Sedangkan untuk model 3 karena jarak netral axisnya lebih panjang menyebabkan lengan momen lebih besar oleh karena itu tegangannya lebih besar.

Setelah tegangan ditentukan selanjutnya mencari berat yang paling ringan dari model $v$-core sandwich panel yang memiliki tegangan kurang dari 46,7 Mpa. Berdasarkan berat tersebut selanjutnnya dibandingkan dengan berat geladak berpenegar. Berat $v$-core sandwich panel harus kurang dari berat geladak berpenegar dengan batasan yang digunakan adalah 34 ton. Seperti yang terlihat pada Tabel 8 sampai dengan Tabel 16 semakin tebal pelat maka berat semakin besar. Ketinggian core tidak mempengaruhi perbedaan berat yang signifikan antara sandwich dengan tinggi 55 mm, 110 $\mathrm{mm}$ dan $220 \mathrm{~mm}$. Model yang paling ringan tentu saja model sandwich dengan tebal pelat face dan core $1 \mathrm{~mm}$ akan tetapi nilai tegangan dan deformasinya sangat besar melebihi tegangan dan deformasi pada geladak berpenegar bahkan melebihi tegangan ijin oleh kelas. Pengurangan berat yang optimum perlu juga ditinjau dari tegangan dan deformasi pada pelat sandwich. Berdasarkan penjelasan tersebut dapat diambil kesimpulan $v$-core sandwich panel yang paling baik adalah model $v$-core sandwich panel dengan tinggi core 110 mm dengan tebal 5-5-5 mm, 5-6-5 mm, 6-5-6 mm. Berikut hasil rekapitulasi running model pada berat tesebut yang dapat dilihat pada Tabel 9.

Tabel 9.

Rekapitulasi Running V-Core Sandwich Panel untuk 3 Model

\begin{tabular}{lccccc}
\hline \hline Jenis Pelat & Tegangan (Mpa) & Deformasi (mm) & Tebal (mm) & Berat (ton) & Perbedaan Berat \\
\hline Geladak Bepenegar & 46.7 & 3.886 & - & 34.174818 & - \\
V-core Sandwich Panel Model 1 (H=110mm) & 44.8 & 3.921 & $5-5-5$ & 28.58207 & $16 \%$ \\
& 44.7 & 3.9 & $5-6-5$ & 30.875442 & $10 \%$ \\
& 44.1 & 3.812 & $6-5-6$ & 32.005123 & $6 \%$ \\
\hline \hline
\end{tabular}

Berdasarkan Tabel 9 geladak v-core sandwich panel yang paling ringan adalah model 1 yang memiliki tinggi core 110 mm dengan tebal 5-5-5 mm dengan berat 28,58207 ton. Berat ini $16 \%$ lebih ringan dari berat geladak berpenegar. Perbedaan konstruksi antara geladak berpenegar dan geladak dengan v-core sandwich panel dapat dilihat pada Gambar 4 dan Gambar 5.

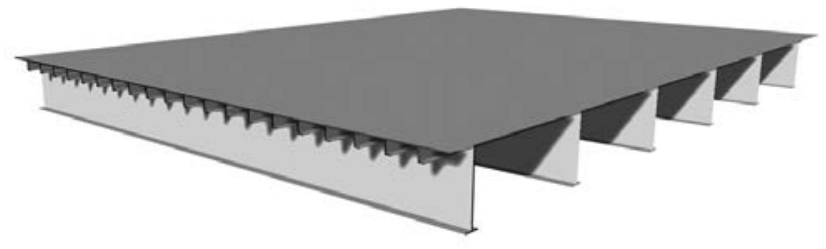

Gambar 4. Model Geladak Berpenegar.
Geladak dengan v-core sandwich panel memiliki bentuk yang sama dengan geladak berpenegar tetapi untuk profil L tidak dimodelkan. Bagian pelat digantikan dengan pelat susunan sandwich yang terdiri dari pelat atas, core dengan bentuk V dan pelat bawah. Secara keseluruhan material yang dipergunakan adalah material baja. Model geladak dengan $v$ core sandwich panel dapat dilihat pada Gambar 5.

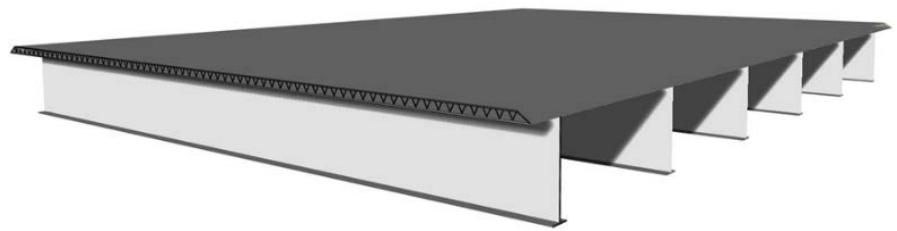

Gambar 5. Model Geladak dengan V-Core Sandwich Panel 


\section{KESIMPULAN}

Setelah dilakukan percobaan dan penelitian tentang desain geladak menggunakan v-core sandwich panel maka kesimpulan dari Studi ini sebagai berikut:

- Desain v-core sanwich panel

Dari hasil percobaan didapatkan desain $v$-core sandwich panel yang paling optimal adalah desain pada model 1 dengan tinggi core $110 \mathrm{~mm}$, ketebalan face 5 $\mathrm{mm}$, ketebalan core $5 \mathrm{~mm}$, jarak antar core $62 \mathrm{~mm}$ dan lebar core $120 \mathrm{~mm}$.

- Hasil running pada model 1 didapatkan besar tegangan yaitu 44,8 Mpa dimana nilai ini sudah kurang dari tegangan ijin dan kurang dari tegangan pelat berpenegar dengan besar deformasi 3,921 mm dan berat 28,5827 ton.

\section{DAFTAR PUSTAKA}

[1] F. A. Marsico, T. A., Denney P.E., "Laser welding of lightweight structural steel panels," in Proceedings of the laser materials processing conference, ICALWO’03, Orlando, 1993.

[2] K. . Ambule, K.G. and Kolhe, "FEM and experimental analysis of stainless steel sandwich panel for weigt reduction," Int. J. Innov. Res. Sci. Technol., 2016.

[3] J. M. Gere, Mechanics of materials. USA: Thompson Learning Book/Cole, 2004

[4] N. R. Center, "Stress and strain,” 2014. [Online]. Available: http://www.nde-ed.org.

[5] B. Haryadi, Teori fisika dasar. Bandung, 2008.

[6] K. Hoque, "Analysis of structural discontinuities in ship hull using finite element method," 2016

[7] D. L. Logan, A first course in the finite element method. Canada: Thomson Canada, Ltd, 2007.

[8] B. K. Indonesia, "Regulation for corrosion protection and coating system," Jakarta, 2005. 